Lindenmann, J. (1957). J. gen. Microbiol. 16, 759-763

\title{
The Staining of Influenza Virus Filaments
}

\author{
BY J. LINDENMANN \\ National Institute for Medical Research, Mill Hill, London, N.W. 7
}

\begin{abstract}
SUMMARY: Influenza virus filaments can be made visible in the ordinary microscope by various staining procedures; a technique involving potassium permanganate and Victoria blue is described.
\end{abstract}

Filamentous structures associated with influenza virus were first observed in electron micrographs by Mosley \& Wyckoff (1946); Chu, Dawson \& Elford (1949) later showed that the filaments could easily be seen in the dark-ground microscope and were particularly numerous in certain freshly isolated strains. The significance of these filaments is not yet fully understood. Some of the fundamental properties of the spherical particles of influenza virus are undoubtedly shared by the filaments: close association with virus infection, capacity to agglutinate red cells and to destroy cell receptors, possession of certain antigenic characters. Whether individual filaments are infectious is open to debate (Donald \& Isaacs, 1954) and so is the question of their role in natural and experimental infection of man and animals.

Electron micrographs of influenza virus filaments have been published by many workers, dark-ground microphotographs by Hoyle (1954). The filaments have a very constant diameter, estimated from sections of bundles of adjacent filaments to be 50-60 m $\mu$. (Morgan, Rose \& Moore, 1956), and are variable in length reaching, in fresh allantoic fiuid, up to $20 \mu$. and more (Burnet, 1956b). On dark-ground observation the filaments are remarkably stiff and show brilliant bodies of apparently larger diameter usually at one end, less commonly at both ends or along their length. These 'knobs' (Burnet, 1956b) can also be seen in the electron microscope; however, since electron microscopy is frequently carried out on virus eluates, which can hardly be prepared without breaking most of the filaments into shorter fragments (Bang \& Isaacs, 1956), many of these pictures do not reveal the high degree of regularity with which terminal bodies can be found in fresh preparations. The filaments seem to be formed as protrusions from the surface of the allantoic cells (Bang, 1955); they are easily disintegrated by various chemical and physical agents (Donald \& Isaacs, 1954; Burnet, 1956a).

The diameter of the filaments lies below the limit of resolution of the light microscope; in phase contrast, therefore, only aggregates of several agglutinated filaments can be seen. So far, nobody seems to have stained filaments in order to make them visible in an ordinary microscope. There is no obvious reason why this should not be possible, since bacterial flagella, which are much thinner, have been successfully stained for the past 70 years. This paper describes a staining method for influenza virus filaments from allantoic fluid. 
Such a method can hardly be expected to throw an exciting new light on virus morphology; it might, nevertheless, prove useful if adaptable to normal histological technique.

\section{METHODS}

Virus. A/Persian Gulf/2/52, a strain of influenza virus which regularly produces a high proportion of filaments, was used in most experiments. MEL, an influenza A strain producing only very few filaments, and uninfected allantoic fluid served as controls. Ten-day-old eggs were infected by the allantoic route from stock capillaries containing seed kept at $-70^{\circ}$ and the fluids were harvested after $48 \mathrm{hr}$. of incubation at $35^{\circ}$. In the case of A/Persian Gulf/2/52 such fluids showed large numbers of filaments on dark-ground examination.

Virus eluates were prepared by absorbing $20 \mathrm{ml}$. allantoic fluid with $0.1 \mathrm{ml}$. of washed packed fowl red cells at $2^{\circ}$ for $30 \mathrm{~min}$., centrifuging the cells at $500 \mathrm{rev} . \mathrm{min}$. for $5 \mathrm{~min}$. and eluting into $10 \mathrm{ml}$. saline at $37^{\circ}$ for $1 \mathrm{hr}$. Antisera were obtained from convalescent ferrets after intranasal infection.

\section{Recommended procedure for staining}

Preparation of slides. Scrupulously cleaned slides free from all traces of grease and dust are placed in a moist chamber and covered with $0.5 \mathrm{ml}$. freshly harvested allantoic fluid or virus eluate. After $1 \mathrm{hr}$., excess fluid is drained off by tilting the slide on to a piece of filter-paper and replaced by $0.5 \mathrm{ml}$. of buffered formalin (Herzberg, 1953). After $15 \mathrm{~min}$. the formalin is poured off and the slide allowed to dry overnight at $37^{\circ}$.

Staining solutions. (A) $1 \%(\mathrm{w} / \mathrm{v})$ aqueous potassium permanganate; (B) 20 parts of $3 \%(\mathrm{w} / \mathrm{v})$ aqueous Victoria blue $4 R+1$ part of saturated aqueous solution of citric acid. These reagents were prepared according to the recommendations of Herzberg (1953) and mixed immediately before use.

Staining schedule. Rapidly pass slide through a Bunsen flame; rinse in tap water; cover with $1 \mathrm{ml}$. solution (A) for $10 \mathrm{~min}$., rinse; cover with $1 \mathrm{ml}$. solution (B) for $30 \mathrm{~min}$., rinse; dry. Filaments appear dark blue-violet on light violet background; cell nuclei are blue-black.

Comment. The preparation must not be allowed to dry before the formalin fixation. Several batches of Victoria blue $\mathbf{4} R$ from different manufacturers have been used with much the same results; however, with some batches, and particularly with freshly prepared solutions, the staining may require a much longer time. Sufficiently stained preparations are, when held against a white sheet of paper, of a perfectly even plain cobalt blue colour. Some immersion fluids bleach the stain in a matter of minutes and must be avoided; the same is true of many current mounting media. A convenient method is to mount the preparation in pure paraffin oil and to ring the coverslip with a paraffin-wax mixture. The proposed staining technique, derived from Herzberg's stain for Paschen bodies (Herzberg, 1953) and from Ruiter's stain for spirochaetes (Ruiter, 1938), lends itself to a number of variations. Thus, the buffered formalin may be replaced by osmium tetroxide vapour; the potassium per- 
manganate may be omitted or replaced by $10 \%(w / v)$ aqueous mercurochrome. This latter variation, yielding preparations in which the cell nuclei are bright red and the filaments pale violet, was suggested by the reports of Craigie (1933) and Vago (1947). Many stains recommended for flagella, Paschen bodies and Treponemata may be suitably adapted to influenza filaments; successful staining was obtained with Leifson's, Löffler's, Zettnow's and Morosow's methods. The silver impregnations, an example of which is given in Pl. 1, fig. 3, might prove useful in histology; they give, when successful, quite impressive pictures.

\section{RESULTS}

Plate 1, fig. 1, shows a preparation of stained influenza virus filaments from fresh allantoic fluid photographed in ordinary light. The terminal bodies or 'knobs', which are a striking feature in the dark-ground microscope, are easily recognized. Granules of similar appearance to the terminal bodies but not connected with the filaments, as well as smaller granules, are scattered throughout the field. Pl. 1, fig. 2, shows virus filaments adsorbed on to fowl red cell ghosts. This preparation, obtained by mixing red cell ghosts and infected allantoic fluid immediately before preparing the slide, gives a good idea of the length of the filaments and of the agglutination mechanism. Pl. 1, fig. 3, shows a virus eluate stained by Zettnow's silver impregnation (Craigie 1929). There is clearly no basic difference between the structures revealed by the Victoria blue and silver techniques. When large numbers of filaments from eluates and fresh allantoic fluids are compared, the former are found to be shorter, indicating that breakage occurs in the process of adsorption and elution. Pl. 1, fig. 4, shows for comparison an electron micrograph of the eluate used in fig. 3, treated with phosphotungstic acid (Hall, 1955) and adjusted to the same magnification. The large gain in resolution from electron microscopy can be more fully appreciated on the original films, from which a fourfold increase in apparent filament diameter with the preparation examined by light microscopy is evident.

No filaments similar to those described were found in uninfected allantoic fluids, in fluids infected with the MEL strain of virus, nor in eluates from this strain. The filaments in a preparation of A/Persian Gulf/2/52 virus could be removed by three cycles of absorption with fowl red cells. On addition of specific virus antiserum, agglutination of the filaments was observed. As a further control, the filaments were watched by dark-ground microscopy through the steps of fixation, mordanting and staining until they emerged into visibility by transmitted light.

\section{DISCUSSION}

The staining of viruses, mainly of the larger pox viruses, has been a controversial matter ever since the description of tiny granules in vaccinial exudates by Buist in $\mathbf{1 8 8 7}$. That the elementary bodies demonstrable by the methods of Paschen, Morosow, Herzberg and others are actually virus corpuscles can no longer be doubted, though the general view about stained preparations is best 
expressed in the words of Burnet \& Andrewes (1933): 'All that can be said is that the normal particle size is less than the apparent size of the stained particles.' 'The difficulty with these very fine structures is not so much one of staining as one of discriminating between virus and background precipitates. This distinction is obviously much easier in the case of filamentous objects. The identity of the stained filaments with those seen in dark-ground and electron microscopy is supported by the following facts: they were found only in allantoic fluids infected with the filamentous strain; they could be removed from such fluids by red cells and recovered in the eluate; they showed agglutination after specific virus antiserum had been added. Finally, all the morphological characteristics of filaments known from electron and dark-ground microscopy are compatible with the stained picture; it is even surprising that such fine details as the terminal bodies, far from being blurred, are rather emphasized by staining. This is the more important since these bodies might represent, as suggested by Burnet $(1956 b)$ the actual infective 'warhead' of the filament.

It is much more difficult to identify the isolated granules seen in the same preparations. Their general aspect and distribution are strongly reminiscent of the spherical particles of influenza virus, but the unequivocal identification of a single granule is almost impossible, stained debris and precipitates being probably always present. From a histological point of view, however, the spheres are less interesting, since it is only from the filaments that we can ever hope to diagnose influenza virus in a tissue section or an impression smear.

I wish to thank Dr C. H. Andrewes, F.R.S., for the interest he took in this work, Dr R. C. Valentine for electron microscopy and Mr M. Young for the photomicrographs. During the work I was in receipt of a fellowship from the Swiss Academy for Medical Sciences.

\section{REFERENCES}

BANG, F. B. (1955). Pathology of the cell infected with viruses-morphological and biochemical aspects. Fed. Proc. 14, 619.

Bang, F. B. \& IsaAcs, A. (1956). Morphological aspects of virus cell relationships with particular reference to the Myxovirus group. The Nature of Viruses. London: Churchill.

Buist, J. B. (1887). Vaccinia and Variola: a Study of their Life History. London: Churchill.

Burnet, F. M. (1956a). Filamentous forms of influenza virus. Nature, Lond. 177, 130.

Burnet, F. M. (1956b). Structure of influenza virus. Science, 123, 1101.

Burnet, F. M. \& Andrewes, C. H. (1933). Über die Natur der filtrierbaren Viren. Zbl. Bakt. (1. Orig.), 130, 161.

Chu, C. M., Dawson, I. M. \& Elford, W. J. (1949). Filamentous forms associated with newly isolated influenza virus. Lancet, ii, 602.

Craigie, J. (1929). The demonstration of bacterial flagella. J. R. micr. Soc. 49, 9.

Craigie, J. (1933). A method for staining the elementary (Paschen) bodies of vaccinia. J. Path. Bact. 36, 185.

Donald, H. B. \& IsaAcs, A. (1954). Some properties of influenza virus filaments shown by electron microscopic particle counts. J. gen. Microbiol. 11, 325. 
Journal of General Microbiology, Vol. 16, No. 3

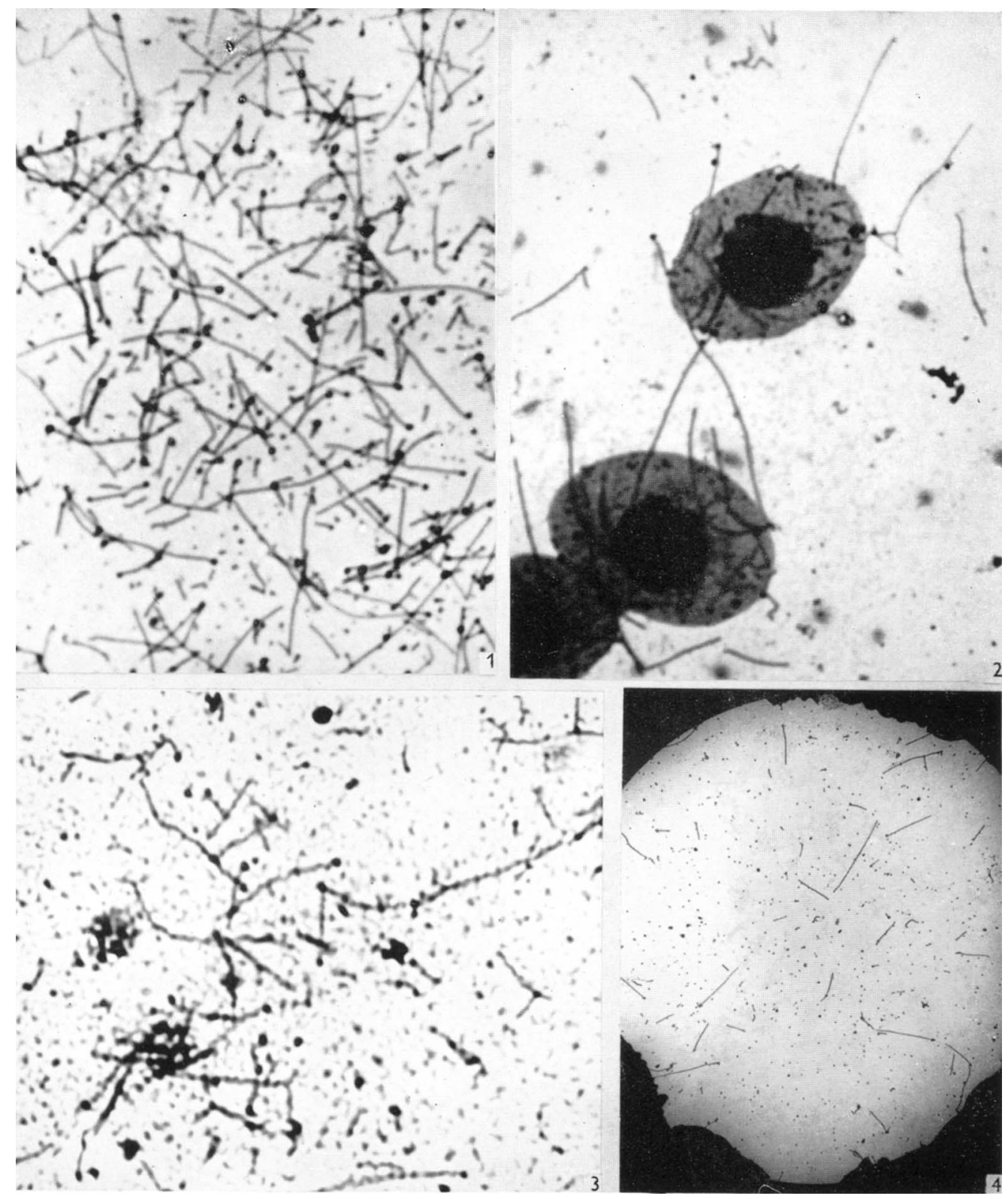

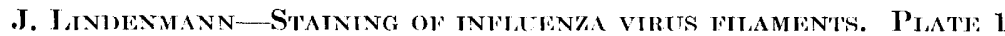


Hall, C. E. (1955). Electron densitometry of stained virus particles. J. biophysic. biochem. Cytol. 1, 1.

Herzberg, K. (1953). Eine Ergänzung der Viktoriablau-Färbung. Z Zbl. Bakt. (1. Orig.), 160, 481.

Hoyle, L. (1954). The release of influenza virus from the infected cell. J. Hyg., Camb. 52, 180.

Morgan, C., Rose, H. M. \& Moore, D. H. (1956). Structure and development of viruses observed in the electron microscope. III. Influenza virus. J. exp. Med. 104, 171.

Mosley, V. M. \& Wyckoff, R. W. G. (1946). Electron microscopy of the virus of influenza. Nature, Lond. 157, 263.

Rurter, M. (1938). Über die Viktoriablaufärbung der Spirochaeta pallida. Derm.Z. $77,27$.

VAGo, S. C. (1947). Méthode de coloration pour l'examen microscopique des spirochètes. Schweiz. med. Wschr. 77, 479.

\section{EXPLANATION OF PLATE}

Figs. 1-3 were photographed with an apochromatic objective of 1.4 N.A., fig. 4 with a Siemens electron microscope. All figures $\times 2400$. Note increase in filament diameter produced by staining.

Fig. 1. Influenza virus from fresh allantoic fluid. Victoria blue.

Fig. 2. Adsorption of influenza virus on laked fowl red cells. Victoria blue.

Fig. 3. Influenza virus from an eluate. Zettnow's silver impregnation.

Fig. 4. Influenza virus from the same eluate as fig. 3. Electron micrograph of a preparation treated with phosphotungstic acid. 